\title{
Analysis of the Integration and Application Mechanism of Folk Art Resources in Art Teaching of Colleges and Universities
}

\author{
Gao Weixin ${ }^{1, a}$ \\ ${ }^{1}$ School of Art and Design, Nanyang Institute of Technology \\ a1720294384qq.com
}

\begin{abstract}
Keywords: Folk art resources, Art teaching of colleges and universities, Influence, Application strategy
\end{abstract}

\begin{abstract}
Folk art resources, as an important part of China's extensive and profound culture, it has rich content and variety of forms, which has far-reaching significance for the art teaching and creation of college and university. This study, in the perspective of folk art resources, takes deep analysis of the influence of folk arts resources on the arts teaching of colleges and universities, besides, it describes in detail the methods of applying folk arts resources in the art teaching of college and university so that to provide important reference for the similar researches.

Folk art is the common form in daily production and it is mainly created by people themselves, which is aimed at beautifying the environment and enriching the folk custom activities. Folk art resources is the basis of arts education of colleges and universities, in order to cultivate application-oriented high-quality talents and make them better serve the local economic and cultural development, promote the inheritance of folk art resources, the colleges and universities should increase the integration of art teaching and folk arts resources so that to build a arts teaching system with local characteristics, finally finish the task of developing, inheriting and innovating folk art in the true sense. The study, starting from the perspective of folk art resources, explores the application and application strategies of folk art resources for art teaching of colleges and universities.
\end{abstract}

\section{The Related Concept of Folk Arts}

The folk art in Modern Chinese Dictionary (revised edition in 2001) refers to the arts form created directly by working people or the widespread arts form in the laboring masses and this form contains music, plastic arts and industrial arts etc. [1]. The definition of folk art in China's art teaching materials is the product of meeting the demand of spirit and life for broad masses of working people and it is the arts product widely used and spread around themselves [2]. Folk art works, as the wisdom crystallization of masses of working group, have been developing along its own development law and become the artistic form of generations for these groups. At present, governments at all levels realize the importance of immaterial cultural inheritance, so they continuously intensify the protection and development of this kind of culture, and get significant results, gradually, the advantages of all kinds of folk art resources translate into economic and competitive advantage. Facts have proven that the local characterized folk art resource is a kind of precious resource and is the main symbol of regional economic development and spiritual civilization. Preparing the local folk art resources protection and development work well has great significance of promoting the local ethnic culture and creating local brand etc. 


\section{Influence of Folk Arts Resources on Arts Teaching}

Folk art teaching, analyzing from one certain level, is the education of national culture, non-material cultural heritage and innovation ability. At present, in the process of arts teaching, most colleges and universities follow the mode of repeating what the book says and break away from students' actual life, which leads to that more and more students are lack of creative inspiration and learning interest in arts. Setting up folk art class in colleges and universities promote students to understand and master deeply China's excellent traditional culture besides, cultivate the national sentiment of new generation. Obviously, adding rich folk art resources into the art teaching of colleges and universities is helpful for the reform and innovation of art teaching. At the same time, the introduction of folk art resources into the folk arts teaching can enrich effectively the arts teaching resources of college and university and promote students' learning interest in this course. For example, the folk art forms of paper cutting, carving etc. have extremely high aesthetic and applied value and it is easy to stimulate students' innovation interest in arts teaching, besides, it can also avoid the disadvantages of simplifying art teaching resource. For example, adding the activities of paper-cutting and embroidery into the arts class of colleges and universities not only can enrich the teaching method, but also can improve students' learning interest and teaching effect [3].

Be Beneficial to Promote Undergraduates’ Comprehensive Quality

As the gradual development of education reform in various regions, the arts classroom teaching are endowed with more teaching tasks, which not only need to cultivate students' creative skills, but also need to pay attention to cultivate students' beauty-appreciation ability etc. Because the folk art resources are derived from the daily life, it not only can show the regional folk customs, also show different codes of conduct and moral codes. For example: the expression of morality, martyrs story etc., which is all saturated with China 's traditional virtue and has a profound education significance [4]. In order to adapt to the future social development need, we need to cultivate talents with exploring spirit and innovative ability. China's traditional folk art resources have distinctive ethnic features and artistic value, which is helpful for students' self-cultivation and then make them get a all around development of moral,intellectual,physical,aesthetics and labor education, which has important impact on the achieving of teaching goal for colleges and universities under the background of quality education. In the process of arts teaching, blending the content above in it not only can enhance the interestingness of art teaching, also can educate students' moral character and beauty-appreciation.

Be Beneficial to Inherit Folk art

The development of China's art industry can't depart from the support of folk art resources and the art industrialization is the product of art and economic development so the modern society attaches great importance to the promotion function of economy on arts. Under the vigorous promotion of market, people's value and consciousness concepts get constant reinforcement and the trend of art products coming into the market are unstoppable. The development of folk art industrialization means that fully open traditional folk art resources and integrate culture idea into the industries to represent the unique artistic and cultural value of folk art resources. The performance of value realizing of art industrialization by folk arts resources is as follows: A The heirs and folk artists are the important force of inheriting and developing folk art, because of the influence of age, environment etc. factors, the majority of folk artists already can't bear the burden of training a large number of art personnel. Folk art, in the future development, can take the method of combining traditional and modern education ways to cultivate good heirs. Colleges and universities, as an important base for students' learning not only shoulder the heavy burden of cultivating the excellent talents, also shoulder the important mission of inheriting and developing 
folk culture. By the non-material culture education to train a large number of talents for folk art industry. With the help of the advantage of abundant human resources in colleges and universities, combining the study with application study to achieve the mutual development of production, learning and research. B Folk craft is the important carrier for displaying the folk art and different crafts embody the designer's life emotion, besides, the personalized folk arts and crafts have the unique value, which can meet the needs of personalized consumption for some people. The folk arts education carried in colleges and universities in the new period should comply with the demand of times development, besides, under the background of studying traditional excellent culture, combine the folk arts resources with tourism and daily used products and then formulate the corresponding communication strategy so that to make the folk art achieve its corresponding artistic value. In this process, the students not only are the promoter of national culture, but also the designers and operators for folk art products.

\section{Categories for the Application of Folk Art Resources in Art Teaching of Colleges and Universities}

\section{Changing of Traditional Art Teaching Concept}

Since the reform and open policy, the arts education business in various region of China has been booming, apart from the traditional eight institutes of fine arts, most comprehensive colleges and universities have set up the fine arts and according to their own development condition, the colleges and universities develop the fine arts courses. For example: the He'nan normal university giving priority to teaching's teaching, its fine arts institute has set up a total of 36 hours of folk art curricula, and Science \&engineering schools only set up 40 hours of folk fine arts courses, besides, some colleges and universities only take the folk art as the professional optional subjects or elective courses. For the fine arts set up in those schools, although they have involved the folk fine arts education in the teaching process, the proportion is smaller besides, the folk art teaching activities are not paid enough importance to in the class [5]. Change the concept of teachers and students in colleges and universities for traditional folk art teaching and constantly try to take innovative teaching, so that to cultivate the applied talents suitable for the social development and promote the exploitation, inheritance and development of local folk art resources in the fine arts teaching of colleges and universities so that to ensure the interrelation between fine arts teaching and students' life in colleges and universities. Therefore, the fine arts teaching in colleges and universities should take the life as the center besides, let the students participate in art practice and then look for and appreciate art in life.

At present, the educators in some colleges and universities have been using the traditional force-feeding teaching method, especially for art teaching, the teaching plans do not tally with the actual teaching activities and lack flexibility. For some schools, the execution of art curricula has same execution standard with other general curricula, and ignores the freedom and individuality demand of arts. As is known to all, the teaching materials have been the important basis of developing fine arts teaching in colleges and universities, therefore, collecting and integrating the unique folk art resources of various regions into the textbook and then showing it is an important content of the fine arts classroom teaching in colleges and universities. The relevant departments of colleges and universities have to strengthen the co-ordination and cooperation between folk artist, artist and education experts and compile teaching materials with local characteristics, furthermore, summarize the concept in the teaching practice, which has important influence on integrating and applying folk art resources and promoting the fine arts teaching effect in colleges and universities. Selecting of Proper Teaching Method 
For students in college and university, developing folk fine arts teaching should be relatively independent and teachers play the leading role in the whole classroom teaching. A Classroom learning mode: In order to help students further study the folk art, the teacher should enrich the forms of classroom teaching, for example: regularly organize folk art exhibition and folk art appreciation activity, etc. so that to let the students study in-depth more works of fine art, and then improve their ability of identifying and appreciating folk art. For example, carry out exhibition, during which period, divide the students into different groups and organizations and organize them to collect students' works to dress up the classroom, besides, evaluate each other team work by each team, finally let the teachers to make the comprehensive evaluation, which can provide students with adequate opportunities to communication and show themselves. B Extracurricular learning mode: folk art extracurricular teaching is to encourage students to use extra-curricular time or day off, oriented by their own interests, to take autonomous learning of folk art resources so that to develop their ability of creation and appreciation. In the process of folk art resources learning, the teacher mainly play the role of reference and guidance. For example, the students in class one of one certain college are generally interested in woodcarving, because the woodcarving process is complicated, and needs to spend a lot of time, the teacher can guide their extracurricular learning of woodcarving craft[6]. Firstly, the art teachers should collect books related to woodcarving and let the students understand the contents of woodcarving culture and its production process etc. Secondly, organize the woodcarving study groups to visit the local or surrounding woodcarving art museums in the weekends, and ask the gallery staff about the woodcarving points. Finally, after fully grasp the woodcarving theory knowledge, organize the team members to practice intensely making woodcarving by spending half a day or a day of the weekends, and after repeated practice, let the students exchange experience so that to lay a solid foundation for the developing of next extracurricular learning. C Innovative teaching mode: Folk art resources should not be confined to the classroom teaching or extracurricular learning and it can continuously broaden students' horizons with the help of the innovation mode 'Coming in' and 'Going out' . 'Coming in' refers to that if the conditions allow, invite the local folk artists to come into the school to develop folk art teaching activities and let the students experience the folk art creation process. This method not only can continuously inherit the achievements of folk art, also can let students experience the simplicity of folk art production so that to make them be more desired for folk art learning, and improve students' interest in learning. Besides, the methods of 'Go Out' are in a variety of forms, for example, the teachers let the students learn regularly in outstanding folk arts and crafts manufactories, artists' house or museums and make full use of the resources of local cultural relics and natural environment,so that to fully understand the culture deposits and background behind folk fine arts resources.

As the organizer of folk art teaching, the teachers should not only have a comprehensive and profound artistic ability, also need a further understanding of the folk fine arts teaching system, which urgently needs the promotion of educators' folk art ability of art major in colleges and universities so that to promote their aesthetic and teaching level. In the integration process of folk art resources and fine arts teaching in colleges and universities, the educators' quality level will play a decisive role. What have to pay attention to is that the existing art teachers team in colleges and universities lack the ready-made folk art teacher. If the colleges and universities lack stable folk art teachers, some teachers may be transferred only after a semester courses, so when they have been familiar with what they taught, they are replaced by other teachers in the next semester, so it is very difficult for these teachers to understand and study folk art resources. Therefore, colleges and universities should allocate fine arts teachers regularly to take further study besides, encourage the 
professional teachers to study folk art and undertake actively the tasks of the folk art teaching. If necessary, we can invite or hire folk artists to give lessons or hold lectures etc. in colleges and universities and gradually reduce the distance between folk art and students in college and universities [7].

\section{Conclusion}

In conclusion, colleges and universities are the important medium to inherit and carry forward the folk fine arts education, in process of developing fine arts teaching, try to introduce the folk fine arts resources as much as possible, which has important influence on inheriting and developing folk art and enriching art teaching forms in colleges and universities etc. This study, based on folk fine arts resources, expounds the influence of folk fine arts resources on fine arts teaching in colleges and universities, besides, puts forward the countermeasures for the application of folk art resources in colleges and universities for the carrying out of art teaching, so that to enrich folk art teaching form and carry forward China's excellent traditional culture.

\section{Bibliography}

[1] Zhangyi.Application Folk Art Resources in Art Teaching[J].Science Newspaper,2015,25(14):36-36.

[2] Zhang Kaiyu.Status and Integrative Strategies of Folk art in Art Teaching of Colleges and Universities[J].Arts Circle,2014,17(9):90.

[3] Song Xuefei.Strategies of Strengthening Folk Art Culture Education for Colleges and Universities in He’nan Province[J].Academic Forum of Nandu,2014,34(6):100-102.

[4] Dongfan.Application of Folk Art Resources in Art Teaching[J]Education for Chinese After-school(Theory)(Midmonth Issue),2015,15(z1):157.

[5] Wang xiaodan.Study of the Integration of Heilongjiang Ethnic and Folk Art Elements into Art Teaching of Colleges and Universities[J].Continuing Education Research,2015,16(5):114-115.

[6] Ye Zilin.Study of the Reassignment Between Art Teaching of Local Colleges and Universities and Local Folk Art Resources[J].Journal of Hubei University of Economics(Humanities \&Social Sciences),2015,13(4):198-199.

[7] Wang Xiaolei.Development and Application of Local Folk and Ethnic Art Resources in Arts Design Education of Colleges and Universities[J].Heilongjiang Researches on Higher Education,2014,23(11):119-121.

About the author: Gao Weixin(1972.9-), male, born in Nanyang city, He'nan province, Bachelor degree and master degreee, lecturer, research direction: Photograph, art and art design, the related teaching, zip code: 473000, work unit: School of Art and Design, Nanyang Institute of Technology, address: Backyard of Fangyuan Express Hotelm, intersection of Guangwu road and Zhongjing road in Nanyang city, te 